Studia Socialia Cracoviensia 7 (2015) nr 1 (12), s. 121-130

http://dx.doi.org/10.15633/ssc. 984

\title{
Maja Bednarska
}

Uniwersytet Papieski Jana Pawła II w Krakowie

\section{Personalistyczne UZasadnienie SkUteczneJ komunikaCjI}

\begin{abstract}
Personalistic fundaments of effective communication. The article contains analysis of human ability of communication. The fundament of my reflexion about communication is philosophy of person. Only communication focused on the person have a chance to be authentic and effective (without any mental barriers or obstacles to communication). This is the main conclusion of this article.

Personalistyczne uzasadnienie skutecznej komunikacji. W moim artykule poddałam analizie zdolność człowieka do komunikowania się. Uczyniłam to z personalistycznego punktu widzenia. W ramach swoich refleksji proponuję tezę, że tylko komunikowanie w perspektywie osoby będzie komunikowaniem autentycznym bez psychologicznych przeszkód czy komunikacyjnych barier.
\end{abstract}

Keywords person, communication, personalism, Karol Wojtyła
osoba, komunikowanie, personalizm, Karol Wojtyła

Teza, że to życie codzienne pokazuje nam, jak istotna jest komunikacja międzyosobowa, wydaje się bardzo lakoniczna. Niemniej jednak zawiera prawdę o kryzysie skuteczności komunikacyjnej, którego wszyscy doświadczamy, chociaż nie zawsze jest on uświadomiony. Dlatego pozostaje on nierozwiązany i przez to warunkuje wiele niepowodzeń komunikacyjnych w codziennej rzeczywistości.

Problem braku skuteczności komunikacyjnej wydaje się nierealny, skoro nieustannie przesyłamy i odbieramy informacje. Rozmawiamy, wysyłamy pocztę elektroniczną, wymieniamy znaczące spojrzenia, przesyłamy uśmiechy, ściskamy dłonie. Bez przerwy do kogoś dzwonimy lub wysyłamy krótkie wiadomości tekstowe. Jednocześnie doświadczamy tego, iż współcześnie, w stechnicyzowanej kulturze mediów jakość komunikowania ulega zmianie. Nasze przekazy stają się mniej rozbudowane, wręcz lakoniczne. Zamiast pogawędek z bliskimi wieczorową porą stukamy w klawiaturę komputera, rozmawiając z kilkoma osobami jednocześnie na platformie komunikatora internetowego. Oglądamy 
telewizję, słuchamy radia. Taki obraz współczesnej rzeczywistości komunikacyjnej niesie zagrożenie uprzedmiotowienia człowieka na rzecz formy czy treści przekazu. Celem artykułu jest ukazanie i jednocześnie uzasadnienie osobowego wymiaru komunikacji między ludźmi. W tym celu rozważania swoje oprę na psychologii komunikacji, która podkreśla osobowy wymiar aktu komunikacyjnego, oraz na personalistycznej filozofii Karola Wojtyły, argumentującej wyjątkowość osoby w kontakcie z drugim człowiekiem.

W swoim artykule, ograniczając się jedynie do komunikacji interpersonalnej, chciałabym również wykazać, dlaczego nauka o komunikowaniu międzyludzkim wymaga odniesienia się do filozofii. Innymi słowy zaznaczyć, że filozofia jako nauka najbardziej uniwersalna nie milczy na temat ludzkiego komunikowania. Określa ona jego status, formę i znaczenie, a przede wszystkim odkrywa jego głębię i odnosi do życia społecznego. Dlatego też trzeba zauważyć, że filozofia wobec nauki o komunikowaniu pełni rolę fundamentalną, definiując sam fenomen komunikowania się międzyludzkiego i obejmując refleksją wszystkie jego formy. I w tym miejscu warto szczególnie zaznaczyć, że to właśnie w filozofii odnajdujemy uzasadnienie dla współczesnych teorii komunikacyjnych, dlaczego w udanym komunikowaniu międzyludzkim najważniejszy jest człowiek, a nie skuteczna forma przekazu. Tu chciałabym sformułować tezę artykułu, że tylko podmiotowe podejście do człowieka w ramach aktu komunikacyjnego zapewni zachowanie jego ontologicznej celowości - porozumienie się międzyludzkie oraz budowanie wspólnej rzeczywistości. W swoich rozważaniach, aby móc uzasadnić powyższe złożenie, przyjmę następujący porządek: najpierw opiszę charakter i znaczenie aktu komunikacyjnego dla człowieka. Potem podejmę próbę uzasadnienia pryzmatu wartości personalistycznej w komunikowaniu się. Następnie postaram się pokazać, w jaki sposób podejście podmiotowe w komunikacji z drugim człowiekiem stanowi komunikacyjny fundament.

Jak już wspomniałam na początku, analizę aktu komunikacyjnego przeprowadzę w kontekście współczesnej filozofii personalistycznej Karola Wojtyły, która w bodaj najbardziej adekwatny sposób będzie pomocna dla podkreślenia istoty osobowego aktu komunikacyjnego, tym samym odpowiadając swoją wymową na potrzeby obecnych czasów. Wykorzystam również psychologię komunikacji międzyosobowej, poprzez co chciałabym pokazać nieodzowność podejścia filozofii personalistycznej w szukaniu drogi do skutecznej komunikacji międzyosobowej. I odwrotnie, odwołując się do filozofii, pragnę odkryć fundament komunikowania, którym jest sam człowiek w swojej istocie, czyli, można powiedzieć, byt w świecie wartości. Generalnie rzecz ujmując, artykuł ten będzie dotyczył raczej spraw podstawowych i fundamentalnych niż konkretnych i partykularnych sytuacji komunikacyjnych. Chciałabym zatem wskazać na konieczność odkrycia osoby w komunikacji interpersonalnej jako warunku nie tyle skutecznej komunikacji, ile fundamentu komunikacji międzyosobowej.

\section{KOMUNIKOWANIE JAKO NATURA CZLOWIEKA}

Już Arystoteles zauważył, że człowiek jest istotą społeczną. Człowiek współegzystuje z innymi i poprzez bycie we wspólnocie projektuje wraz nimi wspólną przyszłość. Takie bycie razem jest możliwe tylko i wyłącznie dzięki porozumiewaniu się, dzięki komunikacji społecznej. Zatem człowiek żyjący we wspólnocie, w społeczeństwie - homo 
socialis - musi mieć zdolność komunikacji, musi być człowiekiem komunikującym się - homo communicans - gdyż właśnie porozumiewanie się nadaje sens życiu w zbiorowości. Ponadto komunikowanie się w obrębie społeczeństwa wywołuje interakcję. Ta natomiast zachodzi podczas procesów wzajemnego oddziaływania na siebie członków wspólnoty ${ }^{1}$. Dzięki czemu społeczeństwo się rozwija, a w konsekwencji kształtuje swoje jednostki.

Słowo „komunikat” pochodzi z języka łacińskiego communicatus i pierwotnie oznaczało użyczenie, a potem współudział, uczestnictwo, obcowanie, wzajemne dzielenie się,

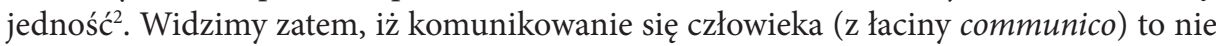
tylko udzielanie informacji, rozmowa czy korespondencja, ale przede wszystkim łączenie się, czyli wspólne przeżywanie, doświadczanie, dzielenie się, współżycie ${ }^{3}$. „Terminowi komunikacja [...] przypisywano przez wieki bardzo różne znaczenia. Oczywiście sens komunii i uczestnictwa [...] dominował w społeczeństwach oralnych"4. Rozumienie omawianego terminu zmieniało się w zależności od czasu, w którym nabywało swój nowy sens, a przede wszystkim od środków używanych do komunikowania się.

Współcześnie przyjmuje się, że „komunikowanie jest rodzajem kontaktu nawiązanego za pomocą zmysłów bądź także specjalnie przystosowanych do tego narzędzi (środków komunikowania) między co najmniej dwiema osobami, z których jedna (nadawca) przekazuje drugiej (odbiorcy) za pomocą zrozumiałych dla nich obu znaków pewne treści pojęciowe lub emocje z zamiarem wywołania u odbiorcy określonych reakcji" ${ }^{\text {. }}$. Można zatem uprościć tę definicję i przyjąć, że komunikowanie to treściowy kontakt za pomocą środków komunikacji z drugą osobą, społecznością, światem, dzięki któremu poznaje innych ludzi i otaczający świat. Aby jednak mogło dojść do aktu komunikacyjnego, niezbędne są jego stałe elementy. Mowa tu oczywiście o nadawcy komunikatu, przekazie jako treści komunikatu oraz odbiorcy przekazu. W wielkim uproszczeniu mówiąc, komunikowanie odbywa się wówczas, kiedy zarówno nadawca, jak i odbiorca przekazu wchodzą we wspólny akt poznawczo-wolitywny. Oznacza to, iż nadawca i odbiorca jednocześnie muszą chcieć podjąć komunikację. „Człowiek komunikuje coś innym, bo chce to czynić i chce coś przez to osiągnąć" . Ponadto bardzo istotną rzeczą jest przy tym dysponowanie wspólnym kodem językowym, tak aby nadawca, kodując treść przekazu, mógł być pewien, że odbiorca przekazu zdoła od-kodować ukrytą informację. Mówiąc o przekazie i kodach językowych, oczywiście mamy na uwadze nie tylko komunikację werbalną, ale również wszelkie inne możliwości komunikacyjne - pozawerbalne. Natura kanału komunikacyjnego, czyli sposobu komunikowania się może być bowiem różna. Może polegać na kontakcie fizycznym, zmysłowym lub intelektualnym osób chcących nawiązać ze sobą kontakt. I właśnie rezultatem podjętych prób porozumienia się jest dobór odpowiedniego rodzaju języka, systemu znaków .

1 Por. B. Szacka, Wprowadzenie do socjologii, Warszawa 2003, s. 122.

2 Por. J. Tokarski, Słownik wyrazów obcych, Warszawa 1980, s. 374.

3 Por. J. Tokarski, Słownik wyrazów obcych, dz. cyt., s. 375.

4 J. Lohisse, Przyszłość kultury zinformatyzowanej, [w:] Antropologia słowa, red. G. Godlewski, A. Mencwel, R. Sulima, Warszawa 2003, s. 658.

5 M. Mrozowski, Media masowe, Warszawa 2001, s. 14.

6 M. Mrozowski, Media masowe, dz. cyt., s. 16.

7 Por. Mrozowski, Media masowe, dz. cyt., s. 17-28. 
W dziejach ludzkości człowiek jako homo socialis żyje i funkcjonuje we wspólnocie dzięki umiejętności komunikowania się. Wszystkie historyczne etapy, które przebył, aby móc skutecznie porozumiewać się z innymi ludźmi, doprowadziły go do cybernetycznej epoki komunikacyjnej. W tym świetle powstaje pytanie o etos komunikowania. Czy jego rola pozostała niezmieniona, czy może uległa zmianie wraz z formą komunikacji?

\section{ETOS WSPÓŁCZESNEGO KOMUNIKOWANIA}

Mając bardzo ogólny zarys procesu komunikacyjnego, możemy zastanowić się nad jego etosem [ethos, z gr. zwyczaj ${ }^{8}$ ]. W dziejach ludzkości komunikacja międzyludzka przybierała różne formy i sposoby. Wynikało to nie tylko z etymologicznego sensu pojęcia, ale przede wszystkim z użytkowej formy, jaką nadał jej dziejowy utylitaryzm. Współcześnie rola komunikacji uległa pewnym zmianom, choć dalej pełni swoje podstawowe funkcje: informacyjną i perswazyjną. Natomiast jej forma jest wprost proporcjonalna do zmieniających się środków komunikacyjnych, czyli jest zależna od nowych mediów.

Pragmatyzm współczesnego świata, podążający za tempem życia, codziennie na nowo pokazuje, że komunikacja międzyludzka powinna przede wszystkim dostarczać jak najwięcej informacji w jak najkrótszym czasie. To przekonanie wzmacniane jest przy okazji kontaktu ze środkami masowego przekazu, od których współczesny sposób życia jest mocno zależny. Dzięki wirtualnej rzeczywistości żyjemy ze świadomością mikro-, ale i makroświata. Stąd też dzisiejsza struktura rzeczywistości ma nie tylko tę płaszczyznę, po której się poruszamy i którą spostrzegamy, ale również tę, w której poruszają się obiekty niewyobrażalnie od nas mniejsze, pokonujące barierę czasu i przestrzeni, dzięki którym działają nasze telefony komórkowe, telewizory czy internet.

W obliczu tego zjawiska powstaje pytanie o to, jak wygląda w świecie na poły stechnicyzowanym ludzki wymiar komunikacji, kultury, mentalności bądź spraw mentalno-etycznych. Wydaje się, że wszystko to, co do tej pory wytworzyło się naturalnym biegiem zdarzeń i rozwoju, będzie przekonwertowane we współczesną technikę, również w środki komunikowania się. Dość wspomnieć o języku czy naturalnych znakach. Powstałe jako naturalne konwencje na drodze ludzkiego rozwoju, w cybernetycznym świecie mają swoje odzwierciedlenia w postaci znaków sztucznych, już nie tyle umownych, co kreowanych hurtowo pogonią technicznego świata. Nadal jednak pozostaje kwestia sfery duchowej człowieka, niedającej się przenieść w sferę artefaktów. Faktem niezaprzeczalnym jest, iż jest ona dostępna tylko i wyłącznie człowiekowi i nie każdy rodzaj komunikacji, szczególne kiedy nadawca i odbiorca kryją się w przestrzeni przedmiotów, jest w stanie uczynić tą sferę komunikowalną. Paradoksem jest więc tutaj zjawisko jednoczesnej redukcji umiejętności komunikowania się. Albowiem wydaje się, że w czasach, kiedy przepływ informacji nie był tak sprawny i szybki, kontakt na płaszczyźnie duchowej był znacznie większy. Natomiast obecnie, w dobie sprintu nowości, sfera ta okazuje się kurczyć, a komunikacja na jej obszarze zanikać. Liczy się puszczona w eter informacja, często bez konkretnego charakteru. Ludzie stali się głodni wiedzy, lecz niestety zatracają zdolność rozumienia siebie nawzajem.

\footnotetext{
8 Por. J. Tokarski, Słownik wyrazów obcych, dz. cyt., s. 203.
} 
Inną kwestią, równie istotną, jest sprawa bezrefleksyjnego stosowania przeróżnych nowoczesnych technik komunikacyjnych w postaci stylu autoprezentacji, sposobu wywierania wpływu, wykorzystania mowy ciała itd. Porozumieniu się między osobami służą one jedynie iluzorycznie, stawiając na pierwszym miejscu raczej cel perswazyjny czy marketingowy. Ukrywają żywą relację i prawdziwą chęć uczestniczenia w dialogu, a wysuwają na plan pierwszy uprzedmiotawianie jednostki i udawanie kogoś, kim się nie jest. Tymczasem nie jest możliwe zbudowanie relacji lub chociażby nawiązanie autentycznej rozmowy w momencie, kiedy nie wyrażamy tego, co czujemy, lecz reagujemy zgodnie z mechanizmem danej techniki. Przeciwnie, to zgoda na bycie sobą, na wejście w autentyczną relację międzyosobową sprzyja dobrej komunikacji ${ }^{9}$.

\section{KOMUNIKACYJNE NIEUZNANIE OSOBY}

Szybkie tempo i konsumpcyjny styl życia, zanik więzi społecznych, niechęć do wchodzenia w głębsze relacje międzyludzkie - to tylko niektóre z symptomów zaniku osobowej jakości współczesnego komunikowania. Mimo to ludzie komunikują nieustannie. Jest to proces tak naturalny, że często odbywa się nieświadomie. A jeżeli nawet jest uświadomiony, to konieczność jego występowania w sposobie ludzkiego bycia czyni go czymś tak naturalnym, że umyka ludzkiej refleksji. Zatem ludzie wiedzą, że komunikują, jednak nie zdają sobie sprawy z jakości tego procesu. Właściwie człowiek zaczyna się zastanawiać nad sposobem swojego komunikowania, kiedy napotyka na trudności w przekazie bądź odbiorze informacji. Wobec czego nie będzie chyba przesadą stwierdzenie, że do refleksji nad aktem ludzkiego komunikowania się skłaniają bariery komunikacyjne.

Jednak kiedy proces komunikacyjny zostanie już zracjonalizowany, a wszelkie trudności wykryte, świadome komunikowanie powinno się opierać na podstawowej kwestii, która objawia się w samej istocie komunikacji - przekaz treści komunikacyjnych odbywa się zawsze między osobami. W tym kontekście bariery komunikacji międzyosobowej, wynikające z szumu informacyjnego, zaburzeń ekspresji interlokutorów, braku umiejętności słuchania czy w końcu z niespójności komunikacji werbalnej z niewerbalną, są jedynie egzemplifikacją i niedoskonałym odzwierciedleniem tego, co stanowi fundament w komunikacji interpersonalnej, czyli bycia człowiekiem. „Oznacza to, iż aby nastąpiła komunikacja interpersonalna, każdy z uczestników musi chcieć i umieć udostępnić coś z tego, co czyni go osobą, oraz być świadomym tego, co czyni osobą kogoś innego"10.

Przyczyny niepowodzenia komunikacyjnego są bardzo różne. Można je mnożyć, w zależności od punktu widzenia sytuacji komunikacyjnej. Dla uproszczenia sprawy proponuję podział barier komunikacyjnych ze względu na sferę osobową komunikacji, czyli sferę nadawcy i odbiorcy; sferę treści przekazu, czyli to, co uczestnicy chcą zakomunikować; oraz sferę okoliczności komunikacyjnej, czyli scenę sytuacji spotkania nadawcy i odbiorcy. Wszystkie trzy sfery spotykają się w akcie komunikacyjnym i bez wątpienia

9 F. Schulz von Thun, Sztuka rozmawiania, t. 1, Analiza zaburzeń, przekł. P. Włodyga, Kraków 2007, s. $268-269$.

10 Mosty zamiast murów. O komunikowaniu się między ludźmi, red. J. Stewart, tłum. J. Suchecki, Warszawa 2010, s. 33. 
przenikają się oraz wzajemnie warunkują. Jednak dla potrzeb niniejszego tekstu ograniczę się jedynie do omówienia tych przeszkód, które występują na poziomie osobowym w komunikacji - czyli na poziomie nadawcy i odbiorcy.

Zaburzenia komunikacyjne, mające źródło w płaszczyźnie osobowej aktu komunikacyjnego, są wynikiem braku uznania drugiej osoby jako partnera do dyskursu. Motywy braku uznania drugiej osoby mogą być różnej natury. Kiedy ujawniają się na gruncie ontologicznym, wówczas odmawia się partnerowi w rozmowie osobistego udziału w kontakcie na rzecz jakiegoś medium, które z natury ogranicza i przekształca proces komunikacyjny. Aksjologiczne argumenty nieuznania drugiej osoby jako partnera do dyskursu przejawiają się w odmowie do zauważenia, przyjęcia czy też przejęcia jego wartości, które reprezentuje. Idąc dalej, można jeszcze wskazać na epistemologiczne czynniki odmowy udziału w dialogu. Występują one wtedy, kiedy nie chcemy, nie potrafimy spostrzegać w podobny sposób rzeczywistości bądź nawet nie wyrażamy gotowości i chęci do podjęcia próby poznania punktu widzenia drugiej strony. Dość wspomnieć o tych trzech sferach, na których w zasadzie głównie opiera się proces nieuznania drugiej osoby jako uczestnika wspólnej komunikacji. A tym samym tworzą się bariery komunikacyjne na płaszczyźnie osobowej w dialogu.

Komunikacja międzyosobowa z konieczności nie może zachodzić tam, gdzie nie ma uznania dla drugiej osoby jako podmiotu komunikacji międzyosobowej. Oznacza to, że spotykają się w tej oto sytuacji, w tej danej chwili te wyjątkowe osoby, które są niemierzalnym dobrem, dokonujące wyboru wspólnego kontaktu, który poddają refleksji, by następnie skonkretyzować w szczególnym przekazie pod konkretnym adresem ${ }^{11}$. Natomiast sam akt komunikacyjny staje się wówczas wspólnym budowaniem rzeczywistości ich otaczającej. Nadawca kieruje przekaz w kierunku odbiorcy, a ten, uznając swój oraz partnera osobowy udział w tej sytuacji, na niego odpowiada. Osobowy, czyli podmiotowy udział w komunikacji międzyosobowej pokazuje się jako współpraca komunikacyjna, wymiana poglądów, wspólne kreowanie znaczeń, zainteresowanie tym, co chce mi przekazać interlokutor. Jednym słowem chodzi o to, aby okazać drugiej osobie szacunek podczas kontaktu z nią. „Wówczas nadawca przez swoją wypowiedź mówi, że traktuje odbiorcę jako godnego uwagi pełnowartościowego partnera rozmowy, że przyznaje mu równe prawa i że ma zamiar okazać mu przychylność"12.

Bariera na tej płaszczyźnie pojawia się również wówczas, gdy odniesienie nadawcy do odbiorcy nie jest podmiotowe, a przedmiotowe. Kiedy nasz interlokutor nie staje się bezpośrednio celem naszej rozmowy, ale środkiem do osiągnięcia jakiegoś innego celu. $\mathrm{Na}$ przykład kiedy natarczywie wypytujemy kogoś o pewne informacje, nie zwracając przy tym uwagi na samą osobę, wówczas mogą pojawić się liczne bariery, trudności komunikacyjne, zaczynając od niechęci do odpowiadania na zadawane pytania, na niewchodzeniu w interakcję komunikacji kończąc. Nieuznanie drugiej osoby w komunikacji interpersonalnej może przybierać również kształt takich konkretnych barier komunikacyjnych, jak: krytykowanie, przezywanie, stawianie diagnozy, chwalenie połączone z oceną, rozkazywanie, grożenie, moralizowanie, zadawanie zbyt wielu lub niewłaściwych pytań,

11 Por. J. Stewart, Komunikacja interpersonalna: kontakt między osobami, [w:] Mosty zamiast murów..., dz. cyt., s. 55.

12 F. Schulz von Thun, Sztuka rozmawiania, dz. cyt., s. 166. 
doradzanie, odwracanie uwagi, logiczne argumentowanie, uspokajanie ${ }^{13}$. Oczywiście nieuznanie drugiej osoby $\mathrm{w}$ komunikacji interpersonalnej to jedna $\mathrm{z}$ wielu spraw stanowiących barierę na tej płaszczyźnie komunikacyjnej. Moim zdaniem jednak - o fundamentalnym znaczeniu dla całego aktu komunikacji.

\section{OSOBA JAKO FUNDAMENT KOMUNIKACJI}

Powyższe rozważania prowadzą nas do momentu, kiedy wypada uzasadnić, dlaczego właśnie traktowanie swojego interlokutora jako podmiot, a nie przedmiot komunikacji międzyosobowej jest właściwym odniesieniem do człowieka w procesie porozumiewania się międzyosobowego. Odpowiedzi na te pytania udziela filozofia personalistyczna. Ukazuje ona bowiem człowieka jako wyjątkowy byt osobowy, któremu z racji przyrodzonej mu godności należy się szacunek i miłośćc ${ }^{14}$.

Jak zostało zatem zapowiedziane na wstępie artykułu, wyjątkowość osoby ludzkiej jest fundamentem komunikowania interpersonalnego, dlatego to właśnie w uznaniu drugiej osoby należy szukać klucza do udanej komunikacji międzyosobowej. Ponieważ nie jest ważne to, że człowiek jest inny, obcy czy to, że nie potrafimy poradzić sobie z własnymi uczuciami, konfliktami czy oporami. Ważne jest to, że w komunikacji interpersonalnej staje przed nami człowiek wraz z bogactwem wartości, które w sposób nieunikniony wnosi razem z sobą w to spotkanie. Karol Wojtyła widział człowieka jako wyjątkowy i wolny byt osobowy, z której to właśnie wolności wynika jego wyjątkowa godność w świecie. Osobą zatem Karol Wojtyła nazywa „taki byt przedmiotowy, który jako podmiot najściślej kontaktuje się z całym światem (zewnętrznym) i najgruntowniej w nim tkwi właśnie przez swoje wnętrze i życie wewnętrzne. Kontaktuje się w ten sposób - trzeba dodać - nie tylko ze światem widzialnym, ale również niewidzialnym, a przede wszystkim z Bogiem"15. W istocie swojej osoba jest bytem, który kontaktuje się z otaczającą ją rzeczywistością. Można zatem powiedzieć innymi słowy, że osoba komunikuje się ze światem i na tym polega dynamika jej życia i rozwoju. Wchodzi w kontakty interpersonalne $\mathrm{z}$ innymi osobami i właśnie w tej sferze powinna podlegać normie personalistycznej. „W tym znaczeniu osoba urzeczywistnia się jako miłość”16.

Bycie z drugim człowiekiem w życiowej praktyce sprowadza się właściwie do tego, że człowiek odkrywa siebie jako istotę społeczną. Jest to fakt, który towarzyszy myśli antropologicznej od samego początku. „Spełnia ją, bytując «z kimś» - i jeszcze głębiej, jeszcze gruntowniej: bytując «dla kogoś». Komunia osób oznacza bytowanie we wzajemnym «dla», w relacji wzajemnego daru. Ta relacja jest wypełnieniem pierwotnej samotności «człowieka»"17. Tak ujęte rozumowanie skłania do traktowania człowieka jako kogoś wyjątkowego, wyróżniającego się w swoim istnieniu spośród innych bytów na ziemi. Więcej, chodzi o afirmację człowieka ze względu na to, że jest osobą. Termin

13 R. Bolton, Bariery na drodze komunikacji, [w:] Mosty zamiast murów..., dz. cyt., s. 175-177.

14 Zob. M. Drożdż, Osoba i media. Personalistyczny paradygmat etyki mediów, Tarnów 2005, s. 39-80.

15 M. Drożdż, Osoba i media..., dz. cyt., s. 25.

16 Jan Paweł II, Przekroczyć próg nadziei, Lublin 1994, s. 150.

17 K. Wojtyła, Mężczyzną i niewiastą stworzył ich, Urbino 1980, s. 52. 
„osoba” został ukuty, aby podkreślić, jak cenny i niepowtarzalny jest człowiek. Bowiem ewangeliczne przykazanie miłości osiąga swoją pełnię tylko wobec drugiego człowieka względem miłości. Karol Wojtyła uważa ponadto, że pełne brzmienie tegoż przykazania realizuje się konkretnie wobec osób, ponieważ sam Bóg, którego przykazanie to dotyczy najpierw, jest najdoskonalszym bytem osobowym.

Osoba właśnie ze względu na ten fakt, że uczestniczy w świecie wartości, przeżywa je w określony sposób. Absorbuje piękno, podąża za dobrem, poszukuje sprawiedliwości, miłuje. Wszystko to czyni, czyli doświadcza wartości, odnośnie do drugiego człowieka. Bycie z drugim człowiekiem, uczestnictwo jest właściwością osoby, w której może spełniać się wartość personalistyczna, w której człowiek szuka szansy na zaistnienie konkretnych wartości dobra, solidarności, bezpieczeństwa, zrozumienia, akceptacji itd. ${ }^{18}$. Wartością, która ma zasadnicze znaczenie w kontaktach międzyludzkich, jest miłość, przez której pryzmat zdaniem Karola Wojtyły powinno się spoglądać na drugiego człowieka. Na tej podstawie sformułował on zasadę normy personalistycznej, która ukazuje pełnię godności osoby ludzkiej. Umożliwia zrozumienie jej istoty ufundowanej w wolności woli oraz wyłania jej potencjał, polegający na urzeczywistnianiu dobra przez miłość. To wszystko sprawia, że osoba jest nośnikiem niezliczonych wartości, tak potrzebnych w obcowaniu z innymi ludźmi, w komunikowaniu się z nimi. W ten sposób przez przykazanie miłości w postaci normy personalistycznej uznajemy osobę ludzką jako szczególnego rodzaju wartość, o której decyduje jej duchowa doskonałość ${ }^{19}$.

\section{KOMUNIKOWANIE OSOBOWE}

Kiedy jeden człowiek spotyka drugiego człowieka, swoim bogactwem tworzą całkiem nową rzeczywistość. Komunikują się między sobą, dzielą się dobrem, zachodzi między nimi proces wymiany wartości. Jednak warunkiem pomyślnej komunikacji międzyosobowej jest umiejętność spoglądania na drugiego człowieka z perspektywy osobowej, przez pryzmat miłości. Filozofia personalistyczna Karola Wojtyły ustala taką perspektywę, ustala normę personalistyczną, która jest miarą bycia z drugim człowiekiem. „Norma ta jako zasada o treści negatywnej stwierdza, że osoba jest takim dobrem, z którym nie godzi się używanie, które nie może być traktowanie jak przedmiot użycia i w tej formie jako środek do celu. W parze z tym idzie treść pozytywna normy personalistycznej: osoba jest takim dobrem, że właściwe i pełnowartościowe odniesienie do niej stanowi tylko miłość”20.

Kiedy podczas komunikacji międzyosobowej jej uczestnicy zdają sobie sprawę z tego, że mimo różnic kulturowych, różnej percepcji rzeczywistości, radykalnie innych światopoglądów oraz bez względu na to, co czują w danej chwili, staje przed nimi człowiek, to znikają wszelkie bariery komunikacyjne. Znikają, ponieważ komunikacja przenosi się na wymiar transcendentny, gdzie nie ma barier w komunikowaniu. Kiedy komunikacja przenosi się na poziom transcendentny, to ludzie zaczynają komunikować się za pomocą wartości. Odtąd nie jest ważne słowo ani gest. I bez względu na to, jak zostałoby

18 K. Wojtyła, Uczestnictwo czy alienacja, [w:] K. Wojtyła, Osoba i czyn, Lublin 2010, s. 459.

19 Por. K. Wojtyła, Osoba i czyn, dz. cyt., s. 109.

20 K. Wojtyła, Miłość i odpowiedzialność, Lublin 2001, s. 42. 
niewyraźnie wypowiedziane lub jakim ładunkiem zostałoby nacechowane, nie ma już słowa. Są wartości, które go niosą. Jeżeli dobra wola rozmówców kieruje treścią przez nich przekazywaną, komunikacja odnosi sukces. Powodem tego jest otwarcie się na odmienną od mojej rzeczywistość drugiego oraz chęć nie tyle dosłownego zrozumienia siebie nawzajem, ile chęć porozumienia. Chęć współodczuwania.

Bardzo dobrym przykładem takiej osobowej formy komunikacji pomimo różnicy zdań, wielu barier komunikacyjnych i częstokroć wielu innych przeszkód jest przyjaźń. Przyjaciele, mimo że często należą do różnych „światów”, starają się znaleźć wspólny język i porozumienie. A czynią to właśnie ze względu na wartość, jaką jest ich przyjaźń i właściwie nie komunikują się przez znaki i symbole, ale przez wartość dobra, opiekuńczości, wsparcia emocjonalnego, zrozumienia, empatii, pomocy w potrzebie, wspólną radość, szczęście drugiego oraz wiele innych wartości, które sobie nawzajem wysyłają, którymi się wymieniają; poprzez które się porozumiewają. Widzą w sobie ludzi odczuwających konkretne emocje, potrzebujących pomocy, zasługujących na określone dobra, pragnących miłości, chcących być słuchanymi i pragnących zainteresowania. Widzą w sobie osoby. Są podmiotem wzajemnej komunikacji, wzajemnego bycia razem. Taki sposób widzenia komunikacji i uwrażliwienia się na drugiego człowieka jako niesamowicie ciekawą osobę i rzeczywistość do odkrycia zapewnia komunikowanie się ponad wszystkimi barierami. Taki sposób widzenia człowieka jest fundamentem komunikacji międzyosobowej - między osobami.

W tym celu, aby „ja” i „ty” mogli przekształcać rzeczywistość mocą woli zaistnienia wartości, które afirmują ich byty, muszą się ze sobą porozumiewać, zgadzać, potwierdzać, ciągle wybierać od nowa, uczestniczyć w swoich wizjach, komunikować. Karol Wojtyła uważa, że „łaciński wyraz communio wskazuje na taką relację pomiędzy osobami, która tylko im jest właściwa. Wskazuje ona równocześnie na dobro, jakim osoby te się obdarzają, udzielając go sobie i zarazem przyjmując od siebie we wzajemnej relacji”"21.

Ontologicznie rzecz ujmując, podstawą komunikacji są dwie osoby, które w sytuacji komunikacyjnej chcą stworzyć nową rzeczywistość. Podjęcie dialogu i otwartość na inność drugiego człowieka wynikają z aksjologicznie ugruntowanego przekonania, że człowiek jako osoba jest wartością nadrzędną, wobec której tylko podmiotowe podejście gwarantuje udaną komunikację. Albowiem główna przyczyna niepowodzenia komunikacyjnego ukryta jest w pierwotnym braku zrozumienia tej jakże bogatej rzeczywistości, która jest przede wszystkim rzeczywistością osób. Przekonanie, że wraz z konkretną osobą - która stoi przede mną w wolności swojego wyboru, odsłaniając przede mną swoją godność, reprezentując swoje wartości - mogę zdobywać konkretne dobro, widzieć konkretne piękno, poznawać w ten sam sposób rzeczywistość czy budować w jednakowy sposób system znaczeń, jest oznaką gotowości do podjęcia z gruntu osobowego dialogu.

Relacja między „ty” i „ja” jest zawsze konkretną sytuacją komunikacyjną. Świadomość tego, że „ty” jest innym, drugim człowiekiem, sprawia, że „ja” poprzez właściwe odniesienie według normy personalistycznej ma świadomość uczestnictwa poprzez miłość w całym człowieczeństwie. Z tego względu drugi człowiek jest zawsze zadaniem do spełnienia, wartością do urzeczywistnienia, potencjałem, który domaga się zaistnienia w dynamice dyskursu. Odpowiadając zatem na postawioną w artykule tezę oraz pytania poboczne, muszę podkreślić raz jeszcze, że wyjątkowość ontologiczno-aksjologiczna osoby sprawia,

${ }^{21}$ K. Wojtyła, U podstaw odnowy, Kraków 1972, s. 54. 
że akt komunikacyjny, z natury swojej będący kontaktem osób, powinien być oparty na świadomości wartości personalistycznej, która się w nim spełnia. Nic innego bowiem, jak podmiotowe podejście do komunikacji, gwarantuje jej udany przebieg. Ponieważ tylko wówczas może zaistnieć bogata rzeczywistość wartości osób, która jest nieodzowna do wzajemnego porozumienia. Kiedy tego brakuje, komunikacja jest powierzchowna, instrumentalna, przedmiotowa i służy nie człowiekowi jako celowi, ale stawia go na pozycji środka do celu innego. I nie chodzi o to, żeby podczas zwykłego pytania o godzinę czynić odbiorcę tegoż przekazu głównym rozmówcą dnia, ale o to, aby okazać mu należny szacunek, czyli w tej konkretnej sytuacji komunikacyjnej - życzliwy uśmiech.

\section{LITERATURA}

Antropologia słowa, red. G. Godlewski, A. Mencwel, R. Sulima, Warszawa 2003.

Drożdż M., Osoba i media. Personalistyczny paradygmat etyki mediów, Tarnów 2005.

Jan Paweł II, Przekroczyć próg nadziei, Lublin 1994.

Mosty zamiast murów. O komunikowaniu się między ludźmi, red. J. Stewart, tłum. J. Suchecki, Warszawa 2010.

Mrozowski M., Media masowe, Warszawa 2001.

Schulz von Thun F., Sztuka rozmawiania, t. 1, Analiza zaburzeń, przekł. P. Włodyga, Kraków 2007. Szacka B., Wprowadzenie do socjologii, Warszawa 2003.

Tokarski J., Słownik wyrazów obcych, Warszawa 1980.

Wojtyła K., Mężczyzna i niewiasta stworzył ich, Urbino 1980.

Wojtyła K., Miłość i odpowiedzialność, Lublin 2001.

Wojtyła K., Osoba i czyn, Lublin 2010.

Wojtyła K., U podstaw odnowy, Kraków 1972. 